\title{
Environmental Enrichment Ameliorates Anxiety-Like Behavior in Rats without Altering Plasma Corticosterone Level
}

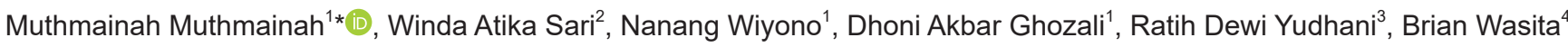 \\ ${ }^{1}$ Department of Anatomy, Faculty of Medicine Universitas Sebelas Maret, Indonesia; ${ }^{2}$ Study Program in Medicine, Faculty of \\ Medicine Universitas Sebelas Maret, Indonesia; ${ }^{3}$ Department of Pharmacology, Faculty of Medicine Universitas Sebelas Maret, \\ Indonesia; ${ }^{4}$ Department of Anatomic Pathology, Faculty of Medicine Universitas Sebelas Maret, Indonesia
}

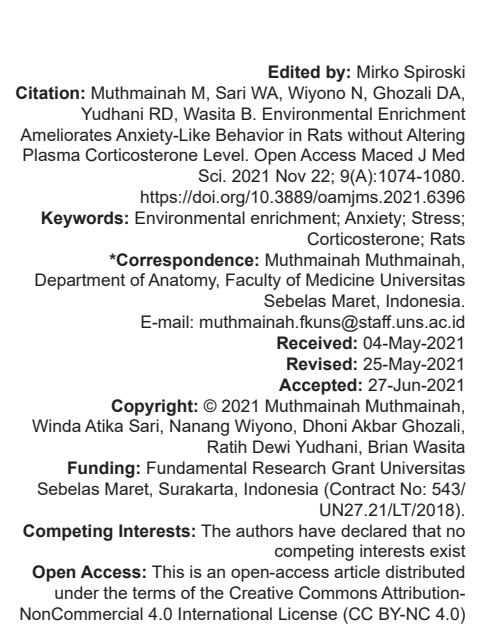

\begin{abstract}
BACKGROUND: Anxiety disorder is one of the most common psychiatric problems. Prolonged stress gives rise to anxiety-like behavior in animals. Environmental interventions influence the outcome of anxiety treatment. Environmental enrichment (EE) can modulate brain's structure and function.

AIM: The objective of the study was to evaluate EE effects on anxiety-like behavior and corticosterone (CORT) leve after unpredictable chronic mild stress (UCMS)

METHODS: A total of 28 rats were assigned into four groups randomly: Control, UCMS, UCMS+EE, and UCMS+fluoxetine. UCMS, EE, and fluoxetine were given for 21 days. Anxiety behavior was measured on day $22^{\text {nd }}$ using Elevated Plus Maze. Behavioral measurement was based on the total time spent and total entries onto open and closed arms. CORT was measured using ELISA.

RESULTS: UCMS increased anxiety-like behavior as seen from reduced number of entries and time spent in open arms as well as increased number of entries and time spent in in closed arms in UCMS group than control. Rats in EE group spent more time and made more entries in the open arms than UCMS group (both $p=0.002$ ). Anxiolytic effect of EE was stronger than fluoxetine. Plasma CORT level among groups did not differ significantly $(p=0.351)$.

CONCLUSION: EE can ameliorate stress-induced anxiety-like behavior without affecting CORT level.
\end{abstract}

\section{Introduction}

Stress is associated with the development of many diseases [1]. Chronic stress can dysregulate the hypothalamic-pituitary-adrenal (HPA) axis with subsequent negative implications on health including psychiatric problems [2]. Prolonged stress exposure can result in maladaptive behavioral changes such as depression and anxiety-like behavior that mimic mental disorders in human [3], [4]. Stress impact was prominent in two brain areas called the hippocampus and amygdala, structures that control the networks for mood regulation, suggesting the important role of stress response in emotional behavior [4].

Anxiety disorder is one of the most common psychiatric problems found in the current societies [5]. Anxiety research in preclinical setting has been focusing on the development of new anti-anxiety drugs [6] probably due to the fact that emotional behavior in human and animal especially rodents are relatively similar [7], [8]. There are three most popular assays that have been adopted in preclinical studies to assess anxiety behavior including the elevated plus maze (EPM) test, the open field (OF) test, and the light-dark (LD) box test [6]. A profound basis from preclinical research is crucial to direct further studies and to develop therapeutic interventions for anxiety disorders [9].

A number of studies suggested the involvement of certain factors such as genes, drugs, and environmental interventions in the management of anxiety [6]. Environmental enrichment (EE) was shown to induce not only morphological and molecular changes in the brain but also changes in the behavior [10], [11]. EE incorporates social and physical stimuli that help modulate brain's function and structure by affecting the expression of certain genes and neurotransmitter's activity [12], [13]. The previous studies showed that EE increased the animal's resilience to stress and inhibited anxiety-like behavior as well as fear induced by stress [14], [15] and restored memory impairment [16]. Despite the EE positive effects on behavior, the mechanism that underlies these effects is not clear yet. Considering these facts, we aimed to investigate whether EE can attenuate stress-induced 
alteration in anxiety behavior and evaluate whether this alteration correlates with any changes in the level of a stress-related hormone, corticosterone (CORT).

\section{Methods}

\section{Animal and housing condition}

Twenty-eight male Wistar rats (Rattus norvegicus) aged approximately 6 weeks were used in this research. Rats were allocated randomly into four groups including control group (C), stress group (UCMS), stress plus EE group (UCMS+EE), and stress plus fluoxetine group (UCMS+Fluox). Each group consisted of seven rats. Rats in the UCMS+EE group were put in an enriched cage to facilitate more physical activity and social interaction. As compared to standard cage, the enriched one was larger $(80 \mathrm{~cm} \times 55 \mathrm{~cm} \times 45 \mathrm{~cm}$ ) and contained various kinds of playing tool such as a small ball, a slide, a running wheel, a plastic tube, bedding material, and a ladder step. These toys were re-positioned regularly to provide novel experience. All other rats were housed in standard cages with controlled lighting at $25-28^{\circ} \mathrm{C}$. The rats could access food and drinking water freely.

\section{Stress protocol}

We applied a chronic unpredictable mild stress (UCMS) procedure in this study. A variety of stressors were given randomly at different time each day to ensure unpredictability as well as to avoid habituation. Stress exposure was given for 21 days to create a chronic state of the stress condition. Detailed protocol of the stress procedure is shown in Table 1.

Table 1: The protocol for chronic unpredictable mild stress

\begin{tabular}{|c|c|c|c|c|}
\hline Day & Time I & Stressor I & Time II & Stressor II \\
\hline 1 & 08.00 & $\begin{array}{l}\text { Cold swimming }\left(10^{\circ} \mathrm{C},\right. \\
4 \mathrm{~min})\end{array}$ & 14.00 & Predator noise (30 min) \\
\hline 2 & 10.00 & Cage tilting at $45^{\circ} \mathrm{C}(4 \mathrm{~h})$ & 18.00 & Overnight illumination \\
\hline 3 & 09.00 & Cage darkened $(3 \mathrm{~h})$ & 17.00 & $\begin{array}{l}\text { Continuous cage shaking } \\
\text { (10 min) }\end{array}$ \\
\hline 4 & 08.00 & Food deprivation (24 h) & 15.00 & Cold swimming $\left(10^{\circ} \mathrm{C}, 4 \mathrm{~min}\right)$ \\
\hline 5 & 08.00 & Cage darkened $(3 \mathrm{~h})$ & 16.00 & Tail pinch (2 min) \\
\hline 6 & 09.00 & Predator noise (30 $\mathrm{min})$ & 18.00 & Overnight illumination \\
\hline 7 & 07.30 & Water deprivation (24 h) & 16.00 & Cage tilting at $45^{\circ} \mathrm{C}(4 \mathrm{~h})$ \\
\hline 8 & 08.00 & Damp sawdust (5 h) & 13.00 & Cold swimming $\left(10^{\circ} \mathrm{C}, 4 \mathrm{~min}\right)$ \\
\hline 9 & 10.00 & Cage darkened ( $3 \mathrm{~h})$ & 17.00 & Predator noise $(30 \mathrm{~min})$ \\
\hline 10 & 06.30 & Predator noise (30 min) & 16.00 & Cage tilting at $45^{\circ} \mathrm{C}(4 \mathrm{~h})$ \\
\hline 11 & 11.00 & $\begin{array}{l}\text { Continuous cage shaking } \\
\text { (10 min) }\end{array}$ & 16.30 & Tail pinch (2 $\mathrm{min})$ \\
\hline 12 & 07.00 & Cage darkened $(3 \mathrm{~h})$ & 17.30 & Overnight illumination \\
\hline 13 & 11.00 & Cage tilting at $45^{\circ} \mathrm{C}(4 \mathrm{~h})$ & 17.00 & $\begin{array}{l}\text { Continuous cage shaking } \\
\text { (10 min) }\end{array}$ \\
\hline 14 & 10.00 & Damp sawdust (5 h) & 15.30 & Cold swimming $\left(10^{\circ} \mathrm{C}, 4 \mathrm{~min}\right)$ \\
\hline 15 & 08.30 & Cage darkened $(3 \mathrm{~h})$ & 18.00 & Overnight illumination \\
\hline 16 & 09.00 & Cage tilting at $45^{\circ} \mathrm{C}(4 \mathrm{~h})$ & 14.00 & Predator noise (30 min) \\
\hline 17 & 08.00 & Tail pinch (2 min) & 16.30 & Cold swimming $\left(10^{\circ} \mathrm{C}, 4 \mathrm{~min}\right)$ \\
\hline 18 & 06.30 & Damp sawdust (5 h) & 12.00 & Cold swimming $\left(10^{\circ} \mathrm{C}, 4 \mathrm{~min}\right)$ \\
\hline 19 & 10.30 & Predator noise (30 $\mathrm{min})$ & 15.00 & $\begin{array}{l}\text { Continuous cage shaking } \\
\text { (10 min) }\end{array}$ \\
\hline 20 & 09.00 & Cage darkened $(3 \mathrm{~h})$ & 18.00 & Overnight illumination \\
\hline 21 & 08.00 & Predator noise (30 $\mathrm{min}$ ) & 15.30 & Cage tilting at $45^{\circ} \mathrm{C}(4 \mathrm{~h})$ \\
\hline
\end{tabular}

\section{Experimental procedure}

After acclimation process, rats were assigned to four groups as previously mentioned. On the $1^{\text {st }}$ day of the experiment, stress exposure as outlined in the UCMS protocol was given to all animals except those in the control group. Enrichment condition and fluoxetine administration were also started from day 1 along with the stress exposure in the UCMS+EE and UCMS+ Fluox group, respectively. Fluoxetine was administered once per day orally at $10 \mathrm{mg} / \mathrm{kg}$ [17]. Immediately before administration, fluoxetine was dissolved with saline $0.9 \%$. Stress exposure, EE, and fluoxetine were given for 21 days. On day 22, the behavioral test was conducted. Blood sample was collected from the retro-orbital plexus on the following day at 9-10 a.m for the measurement of plasma CORT level. The study was conducted as per the guidelines of the Animal Care and Use of Universitas Sebelas Maret. Approval for the study protocol has been given by the Medical Research Ethics Committee of the Faculty of Medicine, Universitas Sebelas Maret, Surakarta, Indonesia (Ethical Clearance 244/UN27.6/KEPK/2018). Every effort was done to minimalize the animals' suffering.

\section{Behavioral test}

On the $22^{\text {nd }}$ day of the experiment, anxiety-like behavior of the animals was measured with EPM test. The EPM test was conducted according to Park et al. previous work [18]. The task used an apparatus with a plus-shaped configuration comprising of two open arms $(50 \mathrm{~cm} \times 10 \mathrm{~cm})$ and two closed arms $(50 \mathrm{~cm} \times 10 \mathrm{~cm} \times$ $40 \mathrm{~cm}$ ) made from white opaque acrylic. The maze was raised $50 \mathrm{~cm}$ from the ground. A video camera placed directly above the middle of the apparatus was used to record the test. Sixty minutes before the test, rats were transported to the behavior testing room. At the start of the examination, the rat was put at the middle of the apparatus $(5 \mathrm{~cm} \times 5 \mathrm{~cm})$ and was then given $5 \mathrm{~min}$ to explore the maze freely. After every session, $70 \%$ ethanol was applied to clean the maze. Before starting the following test, the maze must be clean and dry. An entry is counted when the rat puts all four paws onto the open or closed arm. EPM is a simple yet valid method to evaluate anxiety state in rats. It is developed in accordance with the innate behavior of rats to spontaneously explore novel environment as well as their natural aversion to be in elevated and open areas, thus, creating an exploration conflict. Increased anxiety level and fear is reflected in avoidance of the open arms of the EPM [19]. Anxiety behavior assessment was done by measuring the number of entrances and time spent in each arm. Increased number of entries and the time spent in open arms and rat's tendency to reside in closed arms display higher level of anxiety [20]. Total entries in closed arms are also used to measure the general locomotor activity [21]. 


\section{Plasma CORT measurement}

Immediately after collection, whole blood was processed to obtain the plasma by centrifugation (1500 rcf for fifteen minutes at $4^{\circ} \mathrm{C}$ ). This plasma subsequently was kept in $-20^{\circ} \mathrm{C}$ until ELISA test was performed. The concentration of plasma CORT was measured using ELISA kit (Fine Test, Wuhan Fine Biological Technology Co, Ltd) as per the manufacturer's instruction manual. Absorbance measurement was done at $450 \mathrm{~nm}$ using a spectrophotometer.

\section{Statistical analysis}

One-way analysis of variance (ANOVA) or Kruskal-Wallis test was used to analyze the data followed by Post hoc test for multiple comparisons using SPSS version 22.0. $p<0.05$ was set as the level of significance.

\section{Results}

\section{Behavioral response}

Anxiety-like behavior was assessed based on several parameters including the total entries score and time spent in both the open and closed arms in the EPM test. UCMS significantly reduced entries onto open arms and tended to reduce the time spent in open arms. Rats housed in an enriched condition spent significantly more time in the open arms than rats in the UCMS group $(p=0.002)$ and so did the rats with fluoxetine treatment $(p=0.005)$. This response was stronger in the UCMS+EE group than the UCMS+Fluox group ( $p=0.005)$. Similarly, the number of entries into open arms in both the environmentally enriched group and fluoxetine treated group was significantly higher as compared to UCMS group ( $p=0.002$ and $p=0.017$, respectively). Result of the measurement on total time and entries onto the open arms is displayed in Figure 1.

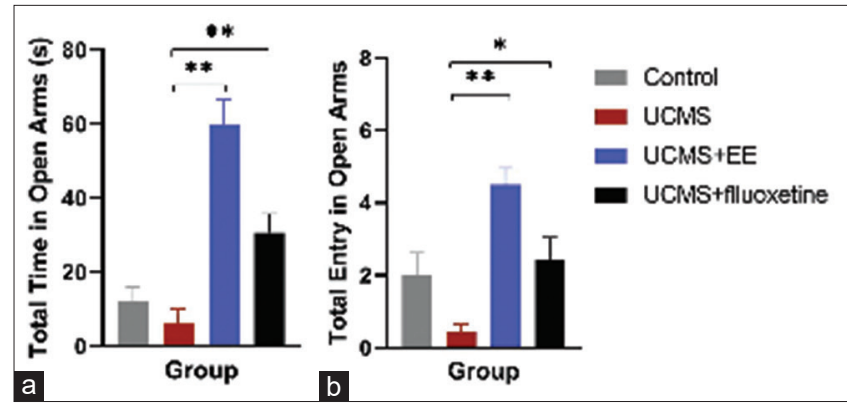

Figure 1: The average total time spent (a) and total entries (b) in open arms in each group depicted as mean + standard error of the mean (SEM). Data were analyzed with one-way analysis of variance followed by Post hoc least significant difference (LSD) test (Data A) and Kruskal-Wallis followed by Post hoc Mann-Whitney test (Data $B$ ). ${ }^{*} p<0.05$ versus unpredictable chronic mild stress (UCMS) group; ${ }^{* *} p<0.01$ versus UCMS group
The number of entries in closed arms of UCMS group was significantly higher as compared to control $(p=0.040)$. The total time spent in closed arms was significantly higher in UCMS group than UCMS+EE group ( $p=0.035)$. Effect of EE in decreasing the total time spent in closed arms was stronger than fluoxetine. The total entries into closed arms in UCMS+EE and UCMS+Fluox group did not differ significantly as compared to UCMS group $(p=0.659$ and $p=0.067$, respectively). Detailed result of the measurement on total time and entries onto the closed arms is displayed in Figure 2.

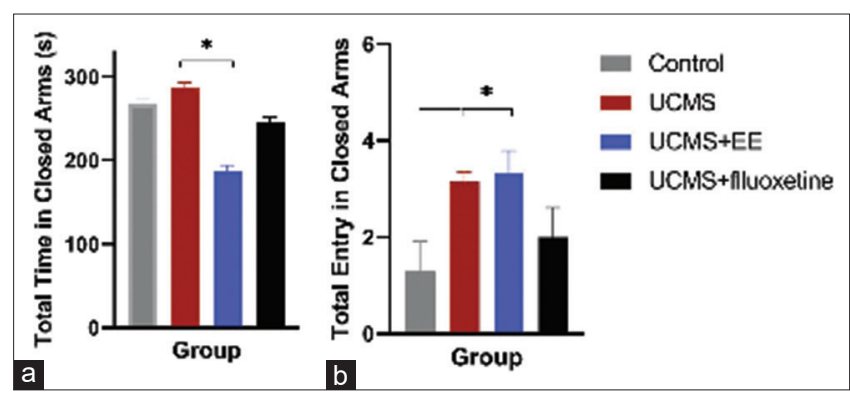

Figure 2: The average total time spent (a) and total entries (b) in Closed Arms in each group presented as mean + standard error of the mean (SEM). Data (a and b) were analyzed with Kruskal-Wallis followed by Post hoc Mann-Whitney test. * $p<0.05$ versus unpredictable chronic mild stress group (a); * $p<0.05$ versus control (b)

\section{Plasma CORT level}

We compared the level of plasma CORT between control, stress group, and treatment group. However, there was no significant difference in the concentration of plasma CORT among groups after we performed the one-way ANOVA analysis.

\section{Discussion}

\section{Behavioral response}

The previous works have suggested the correlation between stressful event and the development of several psychiatric disorders including affective disorders such as anxiety and depression [22], [23], [24]. This study showed that chronic exposure of unpredictable mild stress induced anxiety-like behavior in rodents as indicated by the propensity of the animals to enter the closed arms of the EPM apparatus and to spend most of the time in the closed arms during the test. Rat's preference to be in the closed arms suggests the need for a secure environment reflecting a sign of an anxious state [25]. Consistent with our finding, studies in animals showed that certain kinds of stress exposure resulted in the development of anxiety-like behavior [21], [25], [26]. In line with this result, clinical studies in human also revealed that stress exposure 
increased the risk of developing anxiety disorder [27]. As a response to stress exposure, the HPA axis is stimulated. Stress causes the hypothalamus to secrete a neurohormone called corticotrophin releasing factor (CRF) which subsequently triggers the production of adrenocorticotropic hormone (ACTH) from anterior pituitary. ACTH is released into the bloodstream and then induces the production of glucocorticoid (called CORT in rodents and cortisol in human) from adrenal gland [28]. Stress-related elevation in CRF expression in the amygdala, a structure that regulates emotion, is considered to stimulate anxiety [29]. Moreover, rats with high anxiety state showed increased level of CRFexpressing neurons in the basolateral amygdala [30].

Rats naturally have the fear of height and open spaces as well as the drive to explore new environment. It is generally accepted that the closed arms and the open arms of EPM apparatus can induce similar exploratory drive. Thus, higher level of anxiety is characterized by the aversion of open arm exploration and the propensity to spend time in the closed arms [19]. This study showed that EE could attenuate anxiety-like behavior in rats assessed with EPM paradigm. EE significantly reduced the time spent in the closed arms and increased both the duration in open arms and total entries onto open arms. This change in anxiety behavior was not caused by altered general locomotor activity mainly due to the fact that we did not find any marked differences in the frequency of entries in closed arm between treated groups and UCMS group [21]. Similar to our result, a number of studies found that EE could reduce the level of anxiety in several kinds of animal models [31], [32], [33], [34], [35]. In addition, we found that the anxiolytic effect of EE was stronger than fluoxetine, an antidepressant drug that belongs to serotonine selective reuptake inhibitor (SSRI) group. The previous clinical studies demonstrated that antidepressant (Nutt DJ) could be used to treat anxiety disorders effectively [36] and SSRI was shown to have an anti-anxiety property [37], [38].

The previous research has shown that EE could modulate behavior [39], [40]. It improved the capacity to learn and store memory as well as lowered anxiety level [41], [14], [42]. However, there has been no conclusive evidence regarding the mechanism underlying the anxiolytic effect of EE. There has been no standardized protocol for EE. However, certain components are generally included in the procedure [43]. In this study, we put the UCMS+EE rats in a spacious cage to give them more opportunity to move and provided playing tools to stimulate more social, spatial, sensory, and physical activity. In particular, we put a running wheel to facilitate physical activity. The complexity of EE which incorporates various kinds of stimuli was proven to influence the brain's morphology and function by changing the expression of certain genes and the activity of neurotransmitter [12], [13] which may contribute to the anxiolytic property of EE.

\section{CORT level}

Increased anxiety-like behavior has been associated with elevation in CORT concentration [44]. In contrast, our study suggested that unpredictable chronic mild stress induced an increased anxiety state without any effect on plasma CORT concentration. There was no significant difference in the plasma concentration of CORT among groups ( $p=0.351)$. Neither EE nor fluoxetine administration affected CORT level as compared to both UCMS group and control. This result was somewhat surprising because the previous works indicated that stress exposure elevates the concentration of CORT [45], [46]. Stress-induced emotional disorders in animals also correlated with elevated level of CORT [3], [47], [48]. However, it is noteworthy to see that our findings corroborate previous research showing that rats assigned to EE condition have high resting plasma CORT level as compared to control [49]. Other studies in rats also revealed that neither the basic nor the response level of plasma CORT was affected by EE treatment [50], [51]. In addition, both blockade of CORT secretion and CORT replacement did not normalize the stress-induced alteration in OF behavior following chronic HPA axis disruption [2]. Therefore, it is plausible that CORT regulates behavioral disorders related to stress but may not involve in amelioration of anxiety-like behavior stimulated by EE.

A number of published works showed that many systems plays an important role in the pathophysiology of anxiety disorders including monoaminergic system (serotonergic, dopaminergic, and noradrenergic system) [52] and neuroimmune system [14], [15]. A large cohort study in human also reported an association between immune dysregulation with anxiety disorder [54]. Stress exposure was reported to alter these systems [1], [55], [56], [57]. Thus, it is likely that these systems contributed to alterations in anxiety-like behavior in the EPM test.

\section{Strength and weaknesses}

The stress-induced anxiety model that we used in this study has been widely used in neuroscience research. In addition, anxiety measurement was done using EPM test that has become an established procedure to test anxiety level. It has been validated for usage in both mice and rats [58]. However, we realize that there have been several limitations in this study including the fact that we only measured CORT level at one time point. Thus, we cannot evaluate any changes in the baseline and response CORT level. Additional data from baseline CORT measurement and other stress-related hormone such as CRF will give more support to our study. Further research could investigate the role of other factors that may contribute to the anxiolytic effect of EE such as the neurotransmitter, inflammatory cytokines, and neurotrophic factors 
to gain more understanding on the mechanism that underlies EE effect on anxiety behavior.

\section{Conclusion}

Enriched environment can ameliorate stressinduced anxiety like behavior. This anxiolytic effect is not associated with alteration in stress hormone level.

\section{Author's Contribution}

MM contributed in designing the research, data collecting and analysis, and drafting and revising of the manuscript. WAS was involved in the study conception and design, data analysis and conception as well as providing technical support. NW and DAG contributed to the concept and design of the study; provided statistical expertise and help data interpretation. RDY's expertise in statistic was used in data analysis and interpretation. RDY also critically revised the content of the article and obtained funding. BW's contribution includes study conception and design, statistical expertise, obtaining research funding, and critical revision of the manuscript. Final approval for the manuscript has been given by all authors.

\section{References}

1. Calcia MA, Bonsall DR, Bloomfield PS, Selvaraj S, Barichello T, Howes OD. Stress and neuroinflammation: A systematic review of the effects of stress on microglia and the implications for mental illness. Psychopharmacology (Berl). 2016;233(9):1637-50. https://doi.org/10.1007/s00213-016-4218-9 PMid:26847047

2. Kinlein SA, Phillips DJ, Keller CR, Karatsoreos IN. Role of corticosterone in altered neurobehavioral responses to acute stress in a model of compromised hypothalamic-pituitary-adrenal axis function. Psychoneuroendocrinology 2019;102():248-55. https://doi.org/10.1016/j.psyneuen.2018.12.010 PMid:30594817

3. Skórzewska A, Lehner M, Wisłowska-Stanek A, Krząścik P, Ziemba A, Płaźnik A. The effect of chronic administration of corticosterone on anxiety-and depression-like behavior and the expression of GABA-A receptor alpha-2 subunits in brain structures of low-and high-anxiety rats. Horm Behav. 2014:65(1):6-13. https://doi.org/10.1016/j.yhbeh.2013.10.011 PMid:24200620

4. Anacker C. Adult hippocampal neurogenesis in depression: Behavioral implications and regulation by the stress system. Curr Top Behav Neurosci. 2014;18:25-43. https://doi. org/10.1007/7854_2014_275

\section{PMid:24478038}

5. Kessler RC, Chiu WT, Demler O, Merikangas KR, Walters EE. Prevalence, severity, and comorbidity of 12-month DSM-IV disorders in the national comorbidity survey replication. Arch Gen Psychiatry. 2005;62(6):617-27. https://doi.org/10.1001/ archpsyc.62.6.617

PMid:15939839

6. Farhan M, Ho J, Woo JH, Lim CL, Poon DJJ, Lamba B, et al. Concordance and incongruence in preclinical anxiety models: Systematic review and meta-analyses. Neurosc Biobehav Rev. 2016;68:504-29. https://doi.org/10.1016/j. neubiorev.2016.04.011

PMid:27328783

7. Darwin C, Prodger P. The Expression of the Emotions in Man and Animals. USA: Oxford University Press; 1998.

8. Prut $\mathrm{L}$, Belzung $\mathrm{C}$. The open field as a paradigm to measure the effects of drugs on anxiety-like behaviors: A review. Eur J Pharmacol. 2003;463(1-3):3-33. https://doi.org/10.1016/ S0014-2999(03)01272-X

PMid: 12600700

9. Vesterinen HM, Sena ES, Egan KJ, Hirst TC, Churolov L, Currie GL, et al. Meta-analysis of data from animal studies: A practical guide. J Neurosci Methods. 2014;221:92-102. https:// doi.org/10.1016/j.jneumeth.2013.09.010 PMid:24099992

10. Hirase $\mathrm{H}$, Shinohara $\mathrm{Y}$. Transformation of cortical and hippocampal neural circuit by environmental enrichment. Neuroscience. 2014;280:282-98. https://doi.org/10.1016/j. neuroscience.2014.09.031 PMid:25242640

11. Rosenzweig MR. Environmental complexity, cerebral change, and behavior. Am Psychol. 1966;21(4):321-32. https://doi org/10.1037/h0023555 PMid:5910063

12. Mileva GR, Bielajew C. Environmental manipulation affects depressive-like behaviors in female Wistar Kyoto rats. Behav Brain Res. 2015;293:208-16. https://doi.org/10.1016/j. bbr.2015.07.035

PMid:26215574

13. Hutchinson KM, McLaughlin KJ, Wright RL, Ortiz JB, Anouti DP, Mika A, et al. Conrad, Environmental enrichment protects against the effects of chronic stress on cognitive and morphological measures of hippocampal integrity. Neurobiol Learn Mem. 2012;97(2):250-60. https://doi.org/10.1016/j.nIm.2012.01.003 PMid:22266288

14. Benaroya-Milshtein N, Hollander N, Apter A, Kukulansky $\mathrm{T}$, Raz N, Wilf Al, et al. Environmental enrichment in mice decreases anxiety, attenuates stress responses and enhances natural killer cell activity. Eur J Neurosci. 2004;20(5):1341-7. https://doi.org/10.1111/j.1460-9568.2004.03587.x PMid:15341605

15. Seetharaman S, Fleshner M, Park CR, Diamond DM. Influence of daily social stimulation on behavioral and physiological outcomes in an animal model of PTSD. Brain Behav. 2016;6(5):e00458. https://doi.org/10.1002/brb3.458 PMid:27110436

16. Wright RL, Conrad CD. Enriched environment prevents chronic stress-induced spatial learning and memory deficits. Behav. Brain Res. 2008;187(1):41-7. https://doi.org/10.1016/j. bbr.2007.08.025 PMid:17904657

17. Silva RCB, Brandão ML. Acute and chronic effects of gepirone and fluoxetine in rats tested in the elevated plus-maze: An ethological analysis. Pharmacol Biochem Behav. 2000;65(2):209-16. https://doi.org/10.1016/S0091-3057(99)00193-8 


\section{PMid:10672971}

18. Park HJ, Hyun YK, Yoon KH, Kyung SK, Shim I. The effects of Astragalus membranaceus on repeated restraint stressinduced biochemical and behavioral responses. Korean $\mathrm{J}$ Physiol Pharmacol. 2009;13(4):315-9. https://doi.org/10.4196/ kjpp.2009.13.4.315 PMid:19885016

19. Komada M, Takao K, Miyakawa T. Elevated plus maze for mice J Vis Exp 2008;22(22):e1088. https://doi.org/10.3791/1088 PMid:19229173

20. Leo LM, Pamplona FA. Elevated plus maze test to assess anxietylike behavior in the mouse. Bio-Protocol. 2014;4(16):e1211. https://doi.org/10.21769/bioprotoc.1211

21. Caruso MJ, Crowley NA, Reiss DE, Caulfield JI, Luscher B, Cavigelli SA, et al. Adolescent social stress increases anxiety-like behavior and alters synaptic transmission without influencing nicotine responses in a sex-dependent manner. Neuroscience. 2018;373:182-98. https://doi.org/10.1016/j. neuroscience.2018.01.006

PMid:29343455

22. Muthmainah, Nurwati I. Acupuncture for depression: The mechanism underlying its therapeutic effect. Med. Acupunct. 2016;28(6):301-7. https://doi.org/10.1089/acu.2016.1180

23. Faravelli C, Lo Sauro C, Lelli L, Pietrini F, Lazzeretti L, Godini L, et al. The role of life events and HPA axis in anxiety disorders: A review. Curr Pharm Des. 2012;18(35):5663-74. https://doi. org/10.2174/138161212803530907 PMid:22632471

24. DanielSE, RainnieDG. Stres modulation ofopposing circuits in the bed nucleus of the stria terminalis. Neuropsychopharmacology. 2015;41(1):103-25. https://doi.org/10.1038/npp.2015.178 PMid:26096838

25. Padurariu M, Antioch I, Balmus I, Ciobica A, El-Lethey HS, Kamel MM. Describing some behavioral animal models of anxiety and their mechanistics with special reference to oxidative stress and oxytocin relevance. Int $\mathrm{J}$ Vet Sci Med. 2017;5(2):98-104. https://doi.org/10.1016/j.jijvsm.2017.08.003 PMid:30255057

26. Bondar NP, Lepeshko AA, Reshetnikov VV. Effects of early-life stress on social and anxiety-like behaviors in adult mice: Sexspecific effects. Behav Neurol. 2018;2018:1538931. https://doi. org/10.1155/2018/1538931

\section{PMid:29619126}

27. Koval JJ, Pederson LL, Chan SS. Psychosocial variables in a cohort of students in grades 8 and 11: A comparison of current and never smokers. Prev Med. 2004;39(5):1017-25. https://doi. org/10.1016/j.ypmed.2004.04.006 PMid: 15475037

28. Stephens MA, Wand G. Stress and the HPA axis role of glucocorticoids in alcohol dependence. Alcohol Res. 2012;34(4):468-83.

PMid:23584113

29. Sink KS, Walker DL, Freeman SM, Elizabeth BS, Flandreau I, Ressler KJ, et al. Effects of continuously enhanced corticotropin releasing factor expression within the bed nucleus of the stria terminalis on conditioned and unconditioned anxiety. Mol Psychiatry. 2013;18(3):308-19. https://doi.org/10.1038/ mp.2011.188

PMid:22290119

30. Lehner M, Taracha E, Skórzewska A, Turzyńska D, Sobolewska A, Maciejak P, et al. Expression of C-Fos and CRF in the brains of rats differing in the strength of a fear response. Behav Brain Res. 2008;188(1):154-67. https://doi.org/10.1016/j. bbr.2007.10.033

PMid:18067977
31. Rogers J, Li S, Lanfumey L, Hannan AJ, Renoir T. Environmental enrichment reduces innate anxiety with no effect on depressionlike behavior in mice lacking the serotonin transporter. Behav Brain Res. 2017;332:355-61. https://doi.org/10.1016/j. bbr.2017.06.009

\section{PMid:28629963}

32. Hendershott TR, Cronin ME, Langella S, McGuinness PS, Basu AC. Effects of environmental enrichment on anxiety-like behavior, sociability, sensory gating, and spatial learning in male and female C57BL/6J mice. Behav Brain Res. 2016;314:215-25. https://doi.org/10.1016/j.bbr.2016.08.004

PMid:27498148

33. Meshi D, Drew MR, Saxe M, Ansorge MS, David D, Santarelli L, et al. Hippocampal neurogenesis is not required for behavioral effects of environmental enrichment. Nat Neurosci. 2006;9(6):729-31. https://doi.org/10.1038/nn1696

PMid: 16648847

34. Goes TC, Antunes FD, Teixeira-Silva F. Environmental enrichment for adult rats: Effects on trait and state anxiety. Neurosci Lett. 2015;584:93-6. https://doi.org/10.1016/j. neulet.2014.10.004

PMid:25316162

35. Kazlauckas V, Pagnussat N, Mioranzza S, Kalinine E, Nunes F, Pettenuzzo L, et al. Enriched environment effects on behavior, memory and BDNF in low and high exploratory mice. Physiol Behav. 2011;102(5):475-80. https://doi.org/10.1016/j. physbeh.2010.12.025

PMid:21236277

36. Nutt DJ, Glue P. Imipramine in panic disorder: Clinical response and pharmacological changes. J Psychopharmacol. 1991;5(1):56-64. https://doi.org/10.1177/026988119100500108 PMid:22282120

37. Dincheva I, Yang J, Li A, Marinic BS, Freilingsdorf H, Huang C, et al. Early-life fluoxetine rescues anxiety-like behaviors in BDNF Val66Met mice. Am J Psychiatry. 2017;174(12):1203-13. https://doi.org/10.1176/appi.ajp.2017.15121592 PMid:29084453

38. Gan H, Zhang Q, Zhu B, Wu S, Chai D. Fluoxetine reverses brain radiation and temozolomide-induced anxiety and spatial learning and memory defect in mice. J Neurophysiol. 2019;121(1):298-305. https://doi.org/10.1152/jn.00581.2018 PMid:30517049

39. Diamond MC. Response of the brain to enrichment. An Acad Bras Cienc. 2001;73(2):211-20. https://doi.org/10.1590/ S0001-37652001000200006

PMid:11404783

40. Rosenzweig MR, Bennett EL. Psychobiology of plasticity: Effects of training and experience on brain and behavior. Behav Brain Res. 1996;78(1):57-65. https://doi. org/10.1016/0166-4328(95)00216-2

PMid:8793038

41. Birch AM, McGarry NB, Kelly AM. Short-term environmental enrichment in the absence of exercise, improves memory, and increases NGF concentration, early neuronal survival, and synaptogenesis in the dentate gyrus in a time-dependent manner. Hippocampus. 2013;23(6):437-50. https://doi. org/10.1002/hipo.22103

PMid:23460346

42. Fares RP, Belmeguenai A, Sanchez PE, Kouchi HY, Bodennec J, Morales A, et al. Standardized environmental enrichment supports enhanced brain plasticity in healthy rats and prevents cognitive impairment in epileptic rats. PLoS One. 2013;8(1):e53888. https://doi.org/10.1371/journal. pone.0053888

PMid:23342033 
43. Clemenson GD, Deng W, Gage FH. Environmental enrichment and neurogenesis: From mice to humans. Curr Opin Behav Sci. 2015;4:56-62. https://doi.org/10.1016/j.cobeha.2015.02.005

44. Hestermann D, Temel Y, Blokland A, Lim LW. Acute serotonergic treatment changes the relation between anxiety and HPA-axis functioning and periaqueductal gray activation. Behav Brain Res. 2014;273:155-65. https://doi.org/10.1016/j.bbr.2014.07.003 PMid:25043730

45. Herman JP, McKlveen JM, Ghosal S, Kopp B, Wulsin A Makinson $\mathrm{R}$, et al. Regulation of the hypothalamicpituitary-adrenocortical stress response. Compr Physiol. 2016;6(2):603-21. https://doi.org/10.1002/cphy.c150015 PMid:27065163

46. Ulrich-Lai YM, Herman, JP. Neural regulation of endocrine and autonomic stress responses. Nat Rev Neurosci. 2009;10(6):397-409. https://doi.org/10.1038/nrn2647 PMid:19469025

47. Windle RJ, Shanks N, Lightman SL, Ingram CD. Central oxytocin administration reduces stress-induced corticosterone release and anxiety behavior in rats. Endocrinology. 1997;138(7):2829-34. https://doi.org/10.1210/endo.138.7.5255 PMid:9202224

48. Mitra R, Sapolsky RM. Acute corticosterone treatment is sufficient to induce anxiety and amygdaloid dendritic hypertrophy. Proc Natl Acad Sci USA. 2008;105(14):5573-78. https://doi.org/10.1073/pnas.0705615105

PMid:920222

49. Moncek F, Duncko R, Johansson BB, Jezova D. Effect of environmental enrichment on stress related systems in rats. J Neuroendocrinol. 2004;16(5):423-31. https://doi. org/10.1111/j.1365-2826.2004.01173.x PMid:15117335

50. Pham TM, Ickes B, Albeck D, Soderstrom S, Granholm AC Mohammed $\mathrm{AH}$. Changes in brain nerve growth factor levels and nerve growth factor receptors in rats exposed to environmental enrichment for one year. Neuroscience. 1999;94(1):279-86. https://doi.org/10.1016/S0306-4522(99)00316-4

PMid:10613518
51. Schrijver NC, Bahr NI, Weiss IC, Wurbel H. Dissociable effects of isolation rearing and environmental enrichment on exploration, spatial learning and HPA activity in adult rats. Pharmacol Biochem Behav. 2002;73(1):209-24. https://doi.org/10.1016/ S0091-3057(02)00790-6

PMid:12076740

52. Carrasco A, van de Kar LD. Neuroendocrine pharmacology of stress. Eur J Pharmacol. 2003;463(1-3):235-72. https://doi. org/10.1016/S0014-2999(03)01285-8

PMid:12600714

53. Salim S, Chugh G, Ashgar M. Inflammation in anxiety. Adv Protein Chem Struct Biol. 2012;88:1-25. https://doi.org/10.1016/ B978-0-12-398314-5.00001-5

PMid:22814704

54. Vogelzangs N, Beekman AT, de Jonge P, Penninx BW. Anxiety disorders and inflammation in a large adult cohort. Trans Psychiatry. 2013;3(4):e249. https://doi.org/10.1038/tp.2013.27 PMid:23612048

55. Ossowska G, Nowak G, Kata R, Klenk-Majewska B, Danilczuk Z, Żebrowska-Lupina I. Brain monoamine receptors in a chronic unpredictable stress model in rats. J Neural Transm. 2001;108(3):311-9. https://doi.org/10.1007/s007020170077 PMid:11341483

56. Flügge G, van Kampen M., Mijnste MJ. Perturbations in brain monoamine systems during stress. Cell Tissue Res. 2004;315(1):1-14. https://doi.org/10.1007/s00441-003-0807-0 PMid:14579145

57. Diamond DM, Park CR, Campbell AM, Woodson JC. Competitive interactions between endogenous LTD and LTP in the hippocampus underlie the storage of emotional memories and stress-induced amnesia. Hippocampus. 2005;15(8):1006-25. https://doi.org/10.1002/hipo.20107 PMid:16086429

58. Kumar V, Bhat ZA, Kumar D. Animal models of anxiety: A comprehensive review. J Pharmacol Toxicol Method. 2013;68(2):175-83. https://doi.org/10.1016/j. vascn.2013.05.003

PMid:23684951 